\title{
Exploring Awqā f Governance: Preliminary Evidence of Governance Practices and Disclosure of Two Malaysian Awqāf Institutions
}

\author{
Nur Suriana Awaludin \\ Lecturer, Faculty of Business and Muamalah, \\ International Islamic University College Selangor (KUIS), Malaysia. \\ Hairul Suhaimi Nahar \\ Assistant Professor, Sultan Qaboos University, Muscat, Oman \\ Hisyam Yaacob \\ Instructor, United Arab Emirates University, Al-Ain, U.A.E \\ Nor Suhaily Bakar \\ Lecturer, Faculty of Business and Muamalah, \\ International Islamic University College Selangor (KUIS), Malaysia
}

\begin{abstract}
Sustainable awqāf practices and operations of its managing institutions are primarily influenced by the mutawalli 's (awqāf manager's) accountability created in the environment of good governance. The essences of governance, accountability and sustainability are even more central in the Islamic charitable environment like $a w q q \bar{a} f$ as it plays a unique role as a religious and social-based strategic support device to the existing economy. This paper presents empirical evidence on governance disclosure and practices of two separate Malaysian awqā institutions with different operational setup (corporatized vs. government platform) by using multiple research techniques comprising interviews and documentation reviews. The findings indicate that essences of governance are observable in both entities. However, huge potential for improvement still remains. Exploiting the different operational setup provides indications of measured responses and indirectly suggests the benefits of running waqf operations on a corporatized platform. The results also provide an appropriate basis for a reality check on the mutawalli's governance disclosure and practices.
\end{abstract}

Keywords: Waqf, Governance Practices and Disclosure, Accountability, Sustainability.

KAUJIE Classification: E22, E32. 


\section{Introduction}

Theoretically and practically waqf institutions are usually discussed in a charitable repertoire, however, they generally operate as a hybrid between welfare and a civil society institution (Sait \& Lim, 2005, p. 20 ) which may potentially eradicate poverty by providing quality education, healthcare facilities and employment opportunities (Muhammad, 2010, p. 141). A waqf may be founded for a charitable purpose (waqf $k h a y r \vec{l}$ ), either for community's general benefit (waqf 'àmm) or for a specified use (waqf khāsș). The use may be religious in nature such as a mosque or a cemetery or non-religious such as housing, educational institution or a medical facility. The hadith regarding waqf originally referred to items of real property such as land, mosque and wells. However, socioeconomic changes have made it acceptable for cash, other financial instruments and other items to be dedicated as waqf assets. Allah Almighty says:

(But as for you, O believers,) never shall you attain to true piety unless you spend on others out of what you cherish yourselves; and whatever you spend - verily, God has full knowledge thereof. (Qur'ān, 3:92)

Recently, the literature regarding accountability has grown extensively to explain the multi-dimensional accountability traits of $a w q \bar{a} f$ institutions (e.g. Nahar \& Yaacob, 2011; Ihsan \& Mohamed-Ibrahim, 2011). Among the available literature on accountability, there have been a number of empirical studies also which have sought to establish empirical evidence of the extent to which accountability has been observed by mutawallīs (awq $\bar{a} f$ managers). On the back of these extensive studies remain, however, unique outstanding research issues. Firstly, the majority of prior awqāf studies examine mutawalli's accountability issues from various angles, including but not limited to, accounting, reporting, and operational management. These are collectively argued to be the essences of accountability. Proper accounting, transparent reporting, and effective operational management by mutawallīs are considered as evidence of accountable mutawallīs. The unique issue of governance is however observably scarce within the literature which rarely provides empirical findings of mutawalli's governance reporting and practices. This practically reinforces the need for exploring awqāf governance issues in terms of mutawalli's governance reporting and practices, which constitute the main objective of this paper.

Secondly, prior limited research on awqāf governance was typically conducted using a single mutawalli setting, which is characterized by attributes that contrast to other mutawallis. This renders the empirical results obtained to be unique and hence, non-generalizable to other mutawallīs. Hence, it becomes an empirical question as to whether accountability observance through good governance in the examined mutawallis would be equivalent to that of other mutawallis particularly in a country like Malaysia where $a w q \bar{a} f$ institutions are diverse and heterogenous in their operational setup.

Thirdly, the extent of empirical findings obtained in prior Malaysian research with regards to mutawallis' accountability reflects the fragmentary nature of evidence inconsistent with earlier empirical research. This might partly be due to the prevailing regulatory nature arising from the country's federal constitution which classifies religious matters as state matters with the respective Heads of State (i.e. the Sulțān) possessing full control over administrative issues. This effectively creates dissimilar administrative patterns and hence, potentially, governance reporting and practices among different mutawallis in Malaysian awqāf institutions. This further strengthens the need for examining respective state's specific governance and institutional attributes in the study of mutawallis' accountability. These collectively demonstrate significant empirical gaps in the literature as well as the practical imperative of studying further $a w q \bar{a} f$ governance. The silent nature of the current empirical literature on this issue should be of a great concern to all, given the important roles of both awqāf in Muslims' economies and mutawallīs in managing awqāf assets.

The aim of this exploratory research is, therefore, to investigate selected Malaysian $a w q \bar{a} f$ 's governance reporting and practices. Accordingly, this research reports preliminary empirical results derived from broader research on $a w q \bar{a} f$ accountability from various managerial dimensions. The results presented in this paper are, however, centered on only two specific research issues of governance reporting and practices based on two awqāf institutions whose 
organizational orientation and management styles are observably different. The selection of two distinct mutawallis effectively provides an appropriate investigative platform for exploring the governance reporting and practices of this religiously grounded institution of $a w q \bar{a} f$. The preliminary empirical results are informative at a variety of levels. First, governance reporting is observed to be contrastingly dissimilar across the two mutawallīs, with mutawalli $\mathrm{A}$ who is located in an economically advanced Malaysian State reporting more comprehensive governance information and activities through a variety of reporting channels compared to mutawalli B who operates in another Malaysian State whose economic development is considered to be relatively lower. The same mutawalli with higher governance disclosure quality is also observed to have better governance practices which are almost comparable to governance practices commonly practiced by the for-profit corporations.

The significance and hence the contributions of this research are at least twofold. First, it constitutes the first research attempt at providing fresh empirical evidence of governance reporting and practices among mutawallis whose respective organizational orientation and management styles are observably different. This allows the manipulation of different research settings in examining the accountability traits of governance. Second, the research output is expected to provide vital and relevant policy inputs to stakeholders in charitable spheres and particularly $a w q \bar{a} f$ institutions, specifically on the need and imperative of observing high-quality governance standards covering both reporting and practices.

The remainder of this paper is structured as follows. Section 2 proceeds to review the relevant literature on $a w q \bar{a} f$ and governance in the charity context. This is followed by the research method in section 3. The empirical results and discussions are presented in Section 4. The final section concludes the paper which includes some recommendations and suggested future research.

\section{Waqf and Its Development}

$A w q \bar{a} f$ literature (Alabij, 1989, p.14; Yusof \& Bahari, 1999, p. 108; Alhabshi, 1986, p. 8; Othman, 1982, p. 10) identifies five waqf elements which are:
(1) Wäqif: the person who will be the endower or the founder. The wäqif must have attained the age of bulüghah and be of sound mind and the act of doing waqf must also be done voluntarily;

(2) Mawqüf: the property or capital. The existing property or capital must be completely owned by the wāqif and be free from any encumbrances (Yedyyildiz, 1996, p. 7);

(3) Mawqüf 'alayh: beneficiaries. Whether family members, descendants, or the poor and the general public (ummah); the recipients must not be the enemy of Islam;

(4) Șighah: ìjāb and qabūl of waqf;

(5) The waqfiyyah: waqf foundation charter. This forms another important document during the Ottoman reign where all the assets details, beneficiaries and the mutawalli are listed (Deguilhem, 2003, p. 22).

Waqf literature further explains the characteristics of mutawalli appointed by the wäqifs who must be (1) of sound mind; (2) bāligh (maturity); (3) have amānah (trustworthy); and (4) able to administer and manage the waqf property (Alhabshi, 1986, p. 12, Mehmet, 2011, p. 65). The ultimate purpose of waqf practices is arguably to attain Allah's acceptance as a good deed. The two most common types of awqā are the waqf khayrī (general) and waqf khāsṣ (specific). Recently, however, the cash waqf has become more popular and has been promoted by many waqf managers due to its viability (Nahar \& Yaacob, 2011, p. 89; Sanusi \& Shafiai, 2015, p. 5; Yaacob, Petra, Sumardi, \& Nahar, 2015, p. 230). Moreover, the cash waqf had previously flourished during the Ottoman period (established by Sultāns and well-to-do technocrats and their family members). Those $a w q \bar{a} f$ were very successful especially with the soup kitchen (Singer, 2006) which provided food for the poor, the needy and wayfarers (Cizakca, 1998, p. 5; Toraman, Tuncsiper, \& Yilmaz, 2007, p. 5), books for the madrasah (schools) and a financial institution providing financial loans to the community (Shatzmiller, 1991, p. 195; 2001, p. 45).

Research on awqāf (Islamic endowments) has attracted the attention of Muslim scholars in the late $20^{\text {th }}$ century (Shatzmiller, 2001, p. 44). Countries in the Middle East, Malaysia, Indonesia and Singapore 
are active in the revival of this once important socioeconomic institution apart from zakāh. Although the literature on contemporary waqf properties' management and administration indicates several outstanding issues, efforts by governments and scholars are commended in trying to resolve or at least minimize the risks associated with these problems (Yaacob et al., 2015 , p. 311). The problems are related to various internal and external factors such as mismanagement and misappropriation of $a w q \bar{a} f$ funds ("4 'Illegal, Secret' Accounts Found in Awqaf Ministry”, 2014) and properties (Shatzmiller, 1991, p. 195), including the colonization of Muslim states by Western Imperialists (Cizakca, 1998, p. 44; Hoexter, 1998, p. 475). This could be seen in the examples of British colonization in Palestine and Malaysia and the French in Algeria (Hoexter, 1998, p. 475), Syria and Lebanon (Deguilhem, 2003, p. 7) which nearly paralyzed religious-based institutions. The literature documents evidence of imperialists' actions literally destroying the institutions of waqf and taking over the lands and other properties into their coffers. This was also done to subdue any dissent from the colony and avoid any financial resources from reaching them.

The success story on waqf practices in Algeria was studied by Hoexter (1998) covering the period from the late 1700 s to 1830 . The research found that the preservation of waqf assets (guarding them against dilapidation or usurpation) had ensured continuous distribution of waqf income. The founder prioritized repairs over any other expenditure and that anything endangering waqf assets' continuous presence was ruled out, i.e., selling, mortgage, letting for a permanent/long period were forbidden (only one year for urban and three years for rural). Strict follow-up and efficient control of payments due by tenants and good work in maintaining and restoring of waqf assets under their control are obvious. Reference to the registers shows the purchase of materials for maintenance, and the waqf administrator even kept stocks (inventory) for repair purposes.

\subsection{Governance, Accountability and Transparency in the Charity Context}

The intertwined connection between the three elements of governance, accountability and transparency have been extensively discussed in the existing governance literature in various settings including corporate (Hood \& Heald, 2006; Koh, Laplante, \&
Tong, 2007; Kolk, 2008; Luo, 2005), public sector (not for profit) (Biondi \& Lapsley, 2014; Carnegie \& Wolnizer, 1996; Midin, Joseph, \& Mohamed, 2017) and charity (Connolly \& Hyndman, 2013; Nahar \& Yaacob, 2011; Hyndman \& McDonnell, 2009; Hyndman \& McConville, 2016). The charity context provides a vantage point through which the concept of governance and its traits of accountability and transparency can be examined. The extant literature suggests that accountability and transparency are effectively the supporting pillars of governance, without which the governance system would be ineffective (Biondi \& Lapsley, 2014; Hood \& Heald, 2006; Midin et al., 2017).

A review of governance literature indicates that discussions are noticeably concentrated in the corporate context with literature growing in tandem with many cases of corporate mismanagement and fraud (Cao \& Zhang, 2013, p. 232; Ebrahim; 2005, p. 57; Yaacob \& Basiuni, 2014, p. 506). Equivalent to the corporate context, scandals (financial or otherwise) may also have huge impacts upon charity particularly on donor's confidence as exemplified by the Red Cross case in Shanghai, China (Cao \& Zhang, 2013, p. 235). Yasmin, Haniffa, and Hudaib (2014, p. 105) report that more than $30 \%$ of charities were investigated in the United Kingdom for poor management and financial practices and $11 \%$ of all cases where actions were taken involved Islamic charities. Governance literally means "to direct rule or guide" (Monks \& Minow, 2001, p. 5). In the corporate context, governance refers to the process of controlling, directing and regulating business organizations managed by appointed managers where the shareholders as the main stakeholders have a monetary interest (Monks \& Minow, 2001, p. 5). Apart from ensuring sustainability (Kolk, 2008, p. 2), enhancing firm value and performance (Che-Haat, Abdul Rahman, \& Mahenthiran, 2008, p. 746; Koh et al., 2007, p. 306), governance also controls moral hazards of power by providing a check and balance mechanism (Fama \& Jensen, 1983, p. 303; Jensen \& Meckling, 1976, p. 306).

Jointly discussed and commonly located in the governance literature repertory, the concept of accountability has been frequently defined in the literature in a subtle manner (Connolly \& Hyndman, 2013, p. 262) and the concept can only be appropriately 
understood if it is discussed in a specific (rather than general) context (Crofts \& Bisman, 2010, p. 185). From the organizational lens, accountability relates to the organization's responsibility to demonstrate compliance by way of reporting to a higher authority (Connolly \& Hyndman, 2004, p. 130). Locating accountability in the principal-agency context effectively requires the agent to provide an account (Laughlin, 1990, p. 95) of the entrusted resources given by the principal for performing a specified delegated function (Connolly \& Hyndman, 2013, p. 262). Irrespective of contexts, accountability, therefore, involves the act of elucidating and rationalizing actions in two different time dimensions of past (performed actions and what has been planned) and present (currently performing).

Transparency effectively constitutes the main pillar of governance and hence accountability (Casey, 2006, p. 176; Nahar \& Yaacob, 2011, p. 89). Accounting transparency, for instance, can only serve accountability if it attends the decision usefulness criteria which satisfy users' information needs (Connolly \& Hyndman, 2004, p. 127). In the specific governance context, transparency refers to the act of providing access to the organization's information to the public which covers the organization's operational processes, structures and performance (Etzioni, 2010, p. 392). Accountability is, therefore, part of the process of achieving effective governance the concept of which is related to transparency whereby such activities include the exercise of reporting qualitative and quantitative information and explanation regarding the responsibility to perform a certain function or tasks (Barlev, 2006, p. 174).

Discussion of governance in charitable institutions would normally lead us to the idea that it could generally be classified into internal and external (Ebrahim, 2003, p. 193). The mechanism for the former would be a board of trustees which include internal committees (e.g. compensation and internal audit) whilst the external governance instruments cover accounting rules, reporting requirements, government regulations and external auditors (Hyndman, 1990, p. 297). The roles of governance in charity are essential as it determines the existence of accountability, how accountability is discharged and the types of information produced and the information dissemination methods (Hyndman, 1990, p. 297). In the awqāf context, governance effectively ensures that donors' confidence is kept at the highest level in guaranteeing a continuous flow of contributions, thereby ensuring $a w q \bar{a} f$ institution's survival and sustainability.

Moreover, governance in charitable institutions can reduce conflict with donors by constraining their ability to divert funds to their members or officers and focus more on their charitable activities, reduce transaction costs and make them economically efficient compared to a corporate body (Connolly \& Hyndman, 2004, p. 129). Poor charity governance will subsequently erode stakeholders' confidence and hence adversely affect charitable giving and therefore, charitable activities (Cao \& Zhang, 2013, p. 235; Lecy \& Searing, 2015, p. 542). Accordingly, managing donors' perception through ensuring good governance encapsulating accountable management and reporting transparency to stakeholders is, therefore, critical. For charitable institutions like awqāf, the elements of governance, accountability and transparency are equally important as it ensures a continuous flow of resources from donors or contributors. These elements, therefore, form a basis for effective and efficient operational performance to ensure charities meet legitimate aspirations of their key stakeholders as well as creating a positive reputation that will subsequently attract potential donors and contributors (Connolly \& Dhanani, 2013, p. 109).

\section{Methodology}

In this paper, a mixed mode methodological approach, with a strong emphasis on qualitative techniques, was adopted due to two reasons. First, the nature of research objectives which involve an exploration of unknown phenomenon warrants a quantitative approach infeasible. Second, a mixed mode allows for the generation of rich research results, enabling researchers to capitalize on first-hand information from the qualitative research technique. This mixed mode research project involved the use of robust research techniques including interviews, documentation reviews and physical observations. The governance practices and reporting are investigated premising to the fact that - equivalent to the corporate context poorly governed waqf institutions will only contribute towards the dwindling in donor's confidence, and hence the inevitable demise of waqf practices. 
The two selected mutawallis primarily represent two separate states in Malaysia. In the Malaysian context, the manager of the waqf is only rendered valid by the law of the State Islamic Religious Council (SIRC) of each State. The waqf property is not to be sold, transferred, or inherited because the waqif has relinquished his claim on the said waqf property. Once the property is surrendered to be under waqf, it will become perpetual such that it remains so until the day of judgment with no one able to change it later. The principle of perpetuity is protected by the Sharīah based on a series of rulings such as the prohibition of disposition of the waqf assets through sale and other contracts. In view of the anonymity request by mutawallis in exchange for their agreement to allow the data collection processes, each institution is coded mutawalli $\mathrm{A}$ and $\mathrm{B}$ respectively. Mutawallī A is a corporate entity establishhed in 2011 and independently handles $a w q \bar{a} f$ assets and funds after assuming the roles previously held by the SIRC. It carries a corporatized image as well as a corporate management style. In contrast, mutawallī B falls under The State's Islamic law 1991 (EN. 3/91; Sec. V: Financial no. 7) which effectively empowers the SIRC to became the sole administrator of $a w q \bar{a} f$ assets including general and special $a w q \bar{a} f$ as long as the property is in the State. Unlike mutawalli A, the management of waqf by mutawallī $\mathrm{B}$ is not corporatized. It also handles $A w q \bar{a} f$ Share Units which were officially started on August $1^{\text {st }}, 1999$. The operation is controlled by a section called the Trust Funds of Awqaf Islamic Religious Council (Jawatankuasa Tabung Amanah Saham Wakaf).

Relevant governance documents and information from multiple sources were collected from each mutawalli. To obtain non-observable important data apart from those provided in the relevant published documents, semi-structured interviews, and face-toface conversations with the identified respondents working in the respective institutions were also conducted. The interviews were conducted with the Officers (Mrs. A and Mr. B) which were held in the respective mutawalli's head office in mid-June 2016.

\section{Empirical Results and Discussion}

The results are concentrated on achieving the objective of exploring the current governance practices and disclosure of mutawalli A and B. Several sub-dimensions of governance practices and disclosure are established with the aim of guiding the focus of document review exercises and interview questions. The following Table 1 presents the results obtained. The nature of mutawalli $\mathrm{A}$ is attributed to its corporatized status and has contributed to a more structured governance practice with members of the board consisting of individuals from diverse backgrounds including the presence of a higher proportion of corporate leaders. This is in sharp contrast with mutawalli $\mathrm{B}$ which is a non-corporate entity that operates on a government platform. The bureaucratic nature embedded in mutawallī B's governance structure is sourced from the presence of three royalty members on the board, causing the institution to be more "royalty governed". The bureaucracy in mutawalli B is further reinforced following the relatively bigger size of the board and the presence of active and retired civil servants compared to mutawallī A. These could be a double-edged sword to the institution's governance as board size and experience in the government could work both ways, i.e. improving and/or decaying the governance process.

Another governance element worth noting from the above results is the presence of an active politician on the board in mutawalli B which could also affect the governance environment in both ways. Politicians could improve the governance processes by bringing directly into the board room discussions on topics which could affect the livelihood of the voters. However, politicians could also be controlled remotely by his/her political master and this could adversely affect their independence and conscience in deliberating boardroom issues. Overall, significant differential levels of governance practices across the two mutawallīs are observed with mutawalli A argued to have better governance structures and characteristics relative to mutawalli $\mathrm{B}$. Although this paper is unable to prove empirically that the corporatized nature of the entity caused such a better governance practices in mutawalli A, it could only speculate that more structured governance and ideal board characteristics in mutawallī A compared to mutawallī $\mathrm{B}$ is the measured response of corporatizing an entity whose operations are largely dependent on donors' confidence and contributions. 
Table (1). Governance Practices.

\begin{tabular}{|c|c|c|c|}
\hline No. & Dimensions & Mutawallī A & Mutawallī B \\
\hline 1 & Board Size & - 9 members & - 15 members \\
\hline 2 & Independence & \multicolumn{2}{|c|}{ Majority are outsiders (unrelated to the institution) } \\
\hline 3 & \multicolumn{3}{|l|}{ Director's Profile: } \\
\hline & $\begin{array}{l}\text { - Gender Distribution } \\
\text { - Male } \\
\text { - Female }\end{array}$ & $\begin{array}{l}\text { - } 8 / 9=89 \% \\
\text { - } 1 / 9=11 \%\end{array}$ & $\begin{array}{l}\text { - } 14 / 15=93 \% \\
\text { - } 1 / 15=7 \%\end{array}$ \\
\hline & - Active Politician & - NIL & - $1 / 15=7 \%$ \\
\hline & - Corporate figure(s) & - $3 / 9=33 \%$ & - $3 / 15=20 \%$ \\
\hline & - Royalty member(s) & - NIL & - $3 / 15=20 \%$ \\
\hline & - Retired Civil Servant(s) & - $3 / 9=33 \%$ & - $3 / 15=20 \%$ \\
\hline & - Active Civil Servant(s) & - $3 / 9=33 \%$ & - $9 / 15=67 \%$ \\
\hline & - Education & - $9 / 9=100 \%$ & - $12 / 15=80 \%$ \\
\hline 6 & The presence of separate committees & - Yes & - No \\
\hline 7 & Meeting Frequency & \multicolumn{2}{|l|}{ At least twice a year } \\
\hline 8 & \multicolumn{3}{|l|}{ Meeting's Agenda } \\
\hline & - Endorsement of financial report & \multicolumn{2}{|l|}{ YES } \\
\hline & - Budget approval & \multicolumn{2}{|l|}{ YES } \\
\hline & - Approval of yearly activities & \multicolumn{2}{|l|}{ YES } \\
\hline & - Approval of disbursement & \multicolumn{2}{|l|}{ YES, depending on amount } \\
\hline 9 & Internal Audit & YES & $\mathrm{NO}$ \\
\hline
\end{tabular}

Source: Authors' Own

(Compiled from multiple sources of mutawalli’s websites and interview sessions)

Table (2). Governance Disclosure.

\begin{tabular}{|c|c|c|c|}
\hline No. & Dimensions & Mutawallī A & Mutawalli B \\
\hline 1 & Nature & \multicolumn{2}{|l|}{ Bulletins \& Website } \\
\hline 2 & Mode & \multicolumn{2}{|c|}{ Hard copy: Bulletins \& Soft copy: Website } \\
\hline 3 & Depth of information & Extensive & Limited \\
\hline 4 & BOD activities & \multicolumn{2}{|l|}{ Not Available } \\
\hline 5 & Governance statement & \multicolumn{2}{|l|}{ Not Available } \\
\hline 6 & Governance structure & YES & YES \\
\hline 7 & Director's background & $\begin{array}{ll}\text { - } & \text { Age } \\
\text { - } & \text { Academic } \\
\text { - } & \text { Working experience }\end{array}$ & Not Available \\
\hline
\end{tabular}

Source: Authors' Own

(Compiled from multiple sources of mutawall $\overrightarrow{\mathrm{s}} \mathrm{s}$ websites, bulletins and interview sessions)

The corporate nature of mutawallī A has also contributed towards less opaque governance disclosure and reporting as depicted in Table 2 above. As corporations emphasize stakeholder engagement to remain relevant in the industry, enhanced governance reporting by mutawallī A compared to mutawallī B is not surprising. Whilst both entities report their governance practices through both channels of bulletins and website, the depth of information disclosed is contrastingly different. A large vacuum in the gover- nance information disclosure is, however, noticeable in both entities with critical information on board activities and governance statements not being available for stakeholders' scrutiny. Rudimentary director's characteristics for basic stakeholders' assessment on mutawallī A's governance practices are not directly available from both sources of bulletins and website, requiring stakeholders to request orally from the entity should they require such information. 
The gap in reporting transparency levels between the two mutawallis could potentially be explained by the different management orientation and organizational setup discussed earlier. Equivalent to the discussion on governance practices above, this paper could only speculate that more transparent governance reporting by mutawalli A compared to mutawallī $\mathrm{B}$ constitutes a measured response of corporatization for which the primary aims are to enhance operational efficiency and improve deliverables based on donors' expectations and demands.

\section{Conclusion}

Accountability of religiously grounded organizations like $a w q \bar{a} f$ as viewed from the governance lens is a pressing issue as it is inextricably linked to their sustainability and survival. This is premised on the fact that mutawallin's governance and hence accountability would enhance donors' confidence and subsequently their support, systematically causing waqf's sustainability and survival to become a function of mutawallīs' accountability. It is therefore timely that mutawalli's governance is explored and examined. The results of this research indicate the essence of governance are observable in both sample entities, however, a large potential for improvement remains. Exploiting the different operational setup of corporatized as opposed to government platform setting provides results which point to the differences of running waqf operations in a corporate manner. This conjecture is however purely speculative in nature as no causal relationship based on empirical estimation is offered in this paper, consistent with the empirical results' preliminary status. This, however, offers notable areas for future research. It is recommended that waqf players should respond to the documented results presented above particularly donors who should rightfully demand appropriate information disclosure from the mutawalli with regards to its waqf activities. This would ensure that the mutawalli acts towards enhancing its accountability level. Overall, the empirical evidence presented in this paper (albeit preliminary in nature), improves our understanding of mutawalli's governance practices and reporting towards observing accountability, thereby adding to the growing body of knowledge related to mutawalli's governance and accountability ${ }^{(1)}$.
(1) The funding for this research from both a UPM research grant (GP/IPM 9402200) and a KUIS research grant (GPIK/GPI210005007) are gratefully acknowledged. 


\section{References}

4 'Illegal, Secret' Accounts Found in Awqaf Ministry (2014, September 04). Kuwait Times. Retrieved from: http://news.kuwaittimes.net/4-illegal-secret-accountsfound-awqaf-ministry/

Alabij, A. J. (1989). Perwakafan Tanah di Indonesia: Dalam Teori dan Praktek (Land Awqāf in Indonesia: Theory and Practice). Jakarta: Rajawali Pers.

Barlev, B. (2006). A Biblical Statement of Accountability. Accounting History, 11(2), 173-197.

Biondi, L. \& Lapsley, I. (2014). Accounting, Transparency and Governance: The Heritage Assets Problem. Qualitative Research in Accounting \& Management, 11(2), 146-164.

Cao, L. \& Zhang, L. (2013). Can Audit Play an Effective Role in the Charity Governance? Nankai Business Review International, 4(3), 230-247.

Carnegie, G. D. \& Wolnizer, P. W. (1996). Enabling acco-untability in museums. Accounting, Auditing \& Acco-untability Journal, 9(5), 84-99.

Casey, J. P. (2006). Economic Growth and the Governance of the Financial Sector in the EU: What Role for Regulatory Transparency? In Oxelheim, L. (Ed.), Corporate and Institutional Transparency for Econo-mic Growth in Europe (pp. 173-200), Oxford: Elsevier.

Che-Haat, M. H., Abdul Rahman, R. \& Mahenthiran, S. (2008). Corporate Governance, Transparency and Performance of Malaysian Companies. Managerial Auditing Journal, 23(8), 744-778.

Cizakca, M. (1998). Awqaf in History and its Implications for Modern Islamic Economies. Islamic Economic Studies, 6(1), 43-70.

Connolly, C. \& Dhanani, A. (2013). Exploring the Discharge of E-Countability by Charities. Journal of Applied Accounting Research, 14(2), 108-126.

Connolly, C. \& Hyndman, N. (2004). Performance Reporting: A Comparative Study of British and Irish Charities. The British Accounting Review, 36(2), 127-154.

Connolly, C. \& Hyndman, N. (2013). Charity accountability in the UK: through the eyes of the donor. Qualitative Research in Accounting \& Management, 10(3/4), 259-278.

Crofts, K. \& Bisman, J. (2010). Interrogating accountability: an illustration of the use of Leximancer software for qualitative data analysis. Qualitative Research in Accounting \& Management, 7(2), 180-207.

Deguilhem, R. (2003). On the Nature of Waqf. Pious Foundations in Contemporary Syria: A Break in Tradition. $A W Q A F, 4,5-35$.
Ebrahim, A. (2003). Making Sense of Accountability: Conceptual Perspectives for Northern and Southern Nonprofits. Nonprofit Management \& Leadership, 14(2), 191-212.

Ebrahim, A. (2005). Accountability Myopia: Losing Sight of Organizational Learning. Nonprofit and Voluntary Sector Quarterly, 34(1), 56-87.

Etzioni, A. (2010). Is Transparency the Best Disinfectant? The Journal of Political Philosophy, 18(4), 389-404.

Fama, E. F. \& Jensen, M. C. (1983). The Separation of Ownership and Control. Journal of Law and Economics, 26(2), 301-325.

Alhabshi, S. O. (1986). Konsep Waqaf Dan Perlaksanaannya di Malaysia (The Concept and Implementation of Waqf in Malaysia). Seminar Paper on Management and Administration of Waqf Property, Organized by Majlis Agama Islam Perak and Prime Minister Department. Ipoh, Perak.

Hoexter, M. (1998). Waqf Studies in the Twentieth Century: The State of the Art. Journal of the Economics and Social History of the Orient. 41(4), 474-495.

Hood, C. \& Heald, D. (Eds.). (2006). Transparency: The Key to Better Governance? Oxford: Oxford University Press.

Hyndman, N. (1990). Charity Accounting - An Empirical Study of the Information Needs of Contributors to UK Fund Raising Charities. Financial Accountability \& Management, 6(4), 295-307.

Hyndman, N. \& McDonnell, P. (2009). Governance and Charities: An Exploration of Key Themes and the Development of a Research Agenda. Financial Accountability \& Management, 25(1), 5-31.

Hyndman, N. \& McConville, D. (2016). Transparency in Reporting on Charities' Efficiency: A Framework for Analysis. Nonprofit and Voluntary Sector Quarterly, 45(4), 844-865.

Ihsan, H. \& Mohamed-Ibrahim, S. H. (2011). Waqf Acc-ounting and Management in Indonesian Waqf Institu-tions: The Cases of Two Waqf Foundations. Humano-mics, 27(4), 252-269.

Jensen, M. C. \& Meckling, W. H. (1976). Theory of the Firm: Managerial Behavior, Agency Costs and Ownership Structure. Journal of Financial Economics, 3(4), 305-360.

Koh, P., Laplante, S.K. \& Tong, Y.H. (2007). Accountability and Value Enhancement Roles of Corporate Governance. Accounting and Finance, 47(2), 305-333. 
Kolk, A. (2008). Sustainability, accountability and corporate governance: exploring multinationals' reporting practices. Business Strategy and the Environment, 17(1), 1-15.

Laughlin, R. C. (1990). A Model of Financial Accountability and the Church of England. Financial Accountability \& Management, 6(2), 93-114.

Lecy, J. D. \& Searing, E. A. M. (2015). Anatomy of the Non-profit Starvation Cycle: An Analysis of Falling Overhead Ratios in the Non-profit Sector. Non-profit and Voluntary Sector Quarterly, 44(3), 539-563.

Luo, Y. (2005). Corporate governance and accountability in multinational enterprises: Concepts and agenda. Journal of International Management, 11(1), 1-18.

Mehmet, B. (2011). Economics of Philanthropic Institutions, Regulation and Governance in Turkey. Journal of Economic and Social Research, 13(2), 61-89.

Midin, M., Joseph, C. \& Mohamed, N. (2017). Promoting Societal Governance: Stakeholders' Engagement Disclosure on Malaysian Local Authorities' Websites. Journal of Cleaner Production, 142(4), 1672-1683.

Monks, R. A. G. \& Minow, N. (2001). Corporate Governance (2nd ed.). Oxford: Blackwell Publishing.

Muhammad, I. N. (2010). Scholars, Merchants and Civil Society: Imperative for Waqf-Based Participatory Poverty Alleviation Initiatives in Kano, Nigeria. Humanomics, 26(2), 139-157.

Nahar, H.S. \& Yaacob, H. (2011). Accountability in the Sacred Context: The Case of Management, Accounting and Reporting of a Malaysia Cash Awqaf Institution. Journal of Islamic Accounting and Business Research, 2(2), 87-113.

Othman, M. Z. (1982). Islamic Law with Special Reference to the Institution of Waqf. Kuala Lumpur: Prime Minister's Department, Religious Affairs Division.

Sait, S. \& Lim, H. (2005). Waqf (Endowment) and Islamic Philanthropy, Islam, Land \& Property, Research Series, Nairobi, Kenya: UN-Habitat.
Sanusi, S. \& Shafiai, M. H. M. (2015). The Management of Cash Waqf: Toward Socio-Economic Development of Muslims in Malaysia. Jurnal Pengurusan, 43, 3-12.

Shatzmiller, M. (1991). Some Social and Economic Aspects of Waqf Khayri in the $14^{\text {th }}$ Century Fez. Anaquel de Estudios Arabes, 2, 193-217.

Shatzmiller, M. (2001). Islamic Institution and Property Rights: The Case of the 'Public Good' Waqf'. Journal of the Economics and Social History of the Orient, 44(1), 44-74.

Singer, A. (2006). Soup and Sadaqa: Charity in Islamic Societies. Historical Research, 79(205), 306-324.

Toraman, C., Tuncsiper, B. \& Yilmaz, S. (2007, August). Cash Awqaf in the Ottomans as Philanthropic Foundations and their Accounting Practices. In The 5th Accounting History International Conference (pp. 911), Banff, Canada.

Yaacob, H. \& Basiuni, J. (2014). Corporate Governance Model of a State-Owned Enterprise: Evidence from an Asian Emerging Market. Corporate Governance, 14(4), 504-514.

Yaacob, H., Petra, S., Sumardi, A. \& Nahar, H. S. (2015). Accountability through Accounting and Reporting Lenses: Lessons from an Awqaf Institution in a Southeast Asia Country. Humanomics, 31(3), 299-313.

Yasmin, S., Haniffa, R. \& Hudaib, M. (2014). Communicated Accountability by Faith-Based Charity Organizations. Journal of Business Ethics, 122(1), 103-123.

Yedyyildiz, B. (1996). Place of the Waqf in the Turkish Cultural System (English Translation by R. Acunand M. Oz). Ankara: Hacettepe University.

Yusof, N. M. Z. \& Bahari, A. (1999). Kedudukan dan Potensi Pembangunan Hartanah Waqf di Malaysia: Satu Penilaian (Waqf Property Development Potential in Malaysia: An Analysis). In N. M. N. Hassan (Ed.), Konsep Dan Perlaksanaan Waqf di Malaysia (The Waqf Concept and Its Implementation in Malaysia) (vol. 6, pp. 105-154). Kuala Lumpur: Institut Kefahaman Islam Malaysia (IKIM). 
Nur Suriana Awaludin is currently an accounting lecturer at the Faculty of Business and Muamalah, International Islamic University College Selangor (KUIS), Malaysia. She obtained both her Master's and Bachelor's degree in Accounting from Universiti Teknologi Mara (UiTM), Malaysia and is currently pursuing her PhD study at Universiti Sains Islam Malaysia (USIM) focusing on waqf accounting and governance. Her research interests cover the areas of waqf accounting, governance and financial reporting.

E-mail: suriana@kuis.edu.my

Hairul Suhaimi Nahar is currently attached to the College of Economics and Political Science, Sultan Qaboos University, Muscat, Sultanate of Oman as an Assistant Professor. He obtained his PhD in Corporate governance and financial reporting from the Graduate School of Management (UPM), Master of Science Degree in Accounting from the International Islamic University, Malaysia and a Bachelor Degree in Accounting and Finance from Lancaster University, UK. His research interests cover the areas of takāful and $a w q \bar{a} f$ (operations, accountting and reporting), corporate governance and financial reporting quality.

E-mail: hairul@squ.edu.om

Hisyam Yaacob is an instructor at the Department of Accounting, United Arab Emirate University (UAE). His research interests cover the areas of awqāf accounting and reporting as well as corporate governance.

E-mail: annasham@yahoo.com

Nor Suhaily Bakar is an accounting lecturer at the Faculty of Business and Muamalah, International Islamic University College Selangor (KUIS), Malaysia. She has been teaching accounting information system, financial accounting, costing and managerial accounting since June 2003. She has actively involved in academic writing covering the teaching materials in accounting information system and management accounting and journal articles in various publication outlets. Her research interests cover the areas of accounting information system, financial accounting and reporting and managerial accounting.

E-mail: norsuhaily@kuis.edu.my 


\title{
استكشاف بعض الأدلة البدائية للأوقاف على ممارسة الحوكمة خلال منهج مؤسستين للوقف في ماليزيا
}

\author{
نور سورينا علودين \\ محاضر، كلية الإدارة والمعاملة \\ الكلية الجامعية الإسلامية العالمية، سلانجور، ماليزيا \\ هيرول سحيمي نهار \\ أستاذ مشارك، جامعة سلطان قابوس، مسقط، عمان سئ \\ هشام يعقوب \\ محاضر، جامعة الإمارات العببية المتحدة، العين، عمان \\ نور سحيلي بكر \\ محاضر، كلية الإدارة والمعاملة \\ الكلية الجامعية الإسلامية العالمية، سلانجور، ماليزيا
}

المستخلص. الاستدامة في ممارسة الأوقاف وعمليات مؤسساتها الإدارية تكون متأثرة على الدرجة

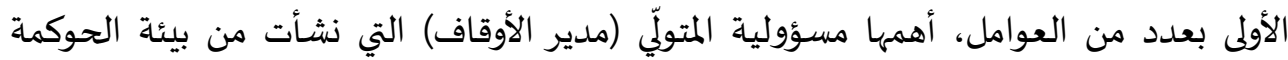
الرشيدة. ويكون الجوهر في موضوع الحوكمة والمسؤولية والاستدامة أكثر تركيزا في المجالات الخيرية الإسلامية مثل الأوقاف لكوها دورة فريدة للمجتمع. وذلك كالجهاز الدعمي للاستراتيجية الأساسية للدين والمجتمع في الاقتصاد القائم. استنادا على ذلك، يقدّم هذا البحث الأدلة التجريبية الأولية

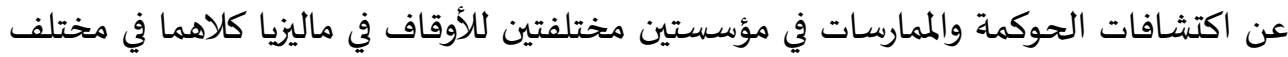
الإعداد التشغيلي (المؤسسة الأهلية مقابلة المؤسسة الحكومية). ويقام تحليل البيانات التجريبية من تعدد مناهج البحث التي تشتمل على المقابلة الشخصية وعرض الوثائق المتعلقة بها. فنتائج البحث تشير إلى أن الجواهر الحوكمية تبدو موجودة في كلا الكيانين مع فرص كبيرة للتحسين.

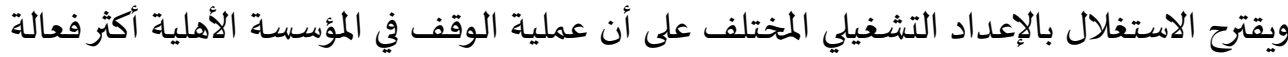
من المؤسسة الحكومية. وفي الخلاصة، توفر نتيجة البحث أساسا ملائما للتحقيق الواقعي في حوكمة المتولي واستدامتها المستقبلية. 